\title{
The Association Between Nutritional Status and Risk of Developmental Disorder in Children in Denpasar Bali Indonesia
}

\author{
I. Gusti Ayu Trisna Windiani*, Ni Kadek Wiwik Agustini* (iD, I. Gusti Agung Ngurah Sugitha Adnyana, Soetjiningsih Soetjiningsih, \\ Ni Luh Sukma Pratiwi Murti
}

Department of Child Health, School of Medicine, Universitas Udayana, Sanglah Hospital, Denpasar, Bali, Indonesia

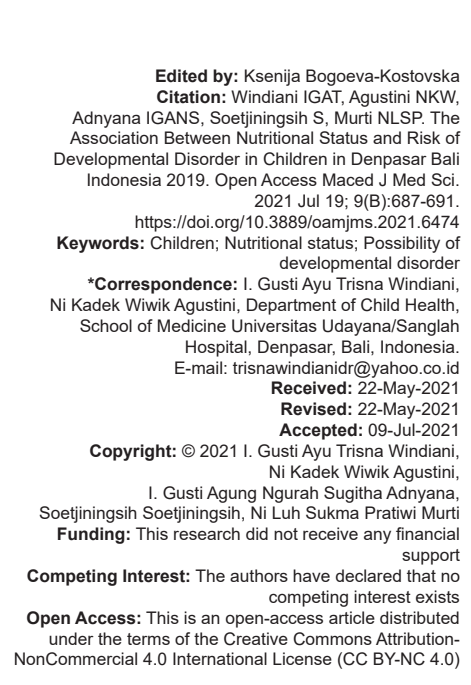

Introduction

Growth and development are continuous processes that occur from conception to adulthood [1], [2]. Childhood is a critical period in growth and development and is the key stage in the formation of their physical and mental abilities [3], [4]. During this stage, physical growth and brain development that are important for learning, intelligence, motor skills, speech and language, as well as social and independence, occurs rapidly [5], [6].

Preschool age is an important period for children's growth and development to prepare themselves for the next stage [7], [8]. Approximately one-third of 30 million children aged 0-6 years in Indonesia have difficulty accessing the early childhood education program (Pendidikan Anak Usia Dini [PAUD]). The Indonesian Ministry of Health reported that $400,000(16 \%)$ Indonesian children under 5 years old have developmental disorders [8]. The incidence of developmental disorders in children under 5 years old can be detected early with a good and effective screening method to prevent overdetection or underdetection.

Nowadays, only very few health workers perform screening for growth and developmental disorders in children due to limited time, knowledge, and skills in using screening instruments. One of the instruments for children developmental screening is the Capute Scale (Cognitive Adaptive Test/Clinical Linguistic Auditory Milestone Scale). Developmental screening using the Capute Scale can accurately determine important aspects of children's development including aspects of language development and visualmotor development by assessing the quantification of the Developmental quotient [9]. Another method that is very easy and fast to detect the possibility of developmental disorder in children is the Indonesian child development pre-screening questionnaire the Kuesioner Praskrining Perkembangan (KPSP). This prescreening method can be carried out by nurses, midwives, medical personnel, and trained paramedics 
to parents in populations to determine whether a child needs further examination. This instrument has a sensitivity of $75 \%$ and a specificity of $99 \%$ compared to the Capute scale as the gold standard [9].

Several factors can affect the development of children in developing countries such as poverty, malnutrition, screen time, physical activity, poor sanitation, and lack of stimulation from the environment [6], [10]. Malnutrition which includes undernutrition and overnutrition is caused by inadequate nutritional intake to meet children's basic needs. Based on the results of Indonesian basic health research (riset kesehatan dasar/Riskesdas) 2018, the prevalence of children under 5 years old with malnutrition in Indonesia reaches $13.8 \%$ [8]. In addition, there is an increased prevalence of other types of malnutrition, which are overnutrition and obesity. Obesity may result in disturbance in children's motor skills, causing them to have decreased endurance and speed in doing physical activities. This will ultimately affect their level of development [10], [11], [12]. Based on this background, the aim of this study is to investigate the relationship between nutritional status and the risk of developmental disorder in preschool children in Denpasar.

\section{Methods}

This study was an observational research with a cross-sectional design to determine the relationship between nutritional status and the risk of developmental disorders in preschool-aged children in Denpasar in 2019. Data were collected at 21 PAUD in Denpasar City by conducting interviews in the form of questionnaire data, direct anthropometric examinations, and prescreening using the KPSP form according to age. Participants were selected using cluster random sampling and a total of 468 preschoolers participated in this study. Participants were excluded if parents refused to give consent to participate in this study. The relationships between variables were analyzed and presented using the Chi-square test.

Nutritional status was determined based on anthropometric data, body weight and body height, which are then classified according to Waterlow's criteria. The risk of developmental disorder was assessed using KPSP according to the child's age. The results were categorized as "appropriate developmental stage" if the score was 9-10 and "inappropriate developmental stage" if the score was below 8 (doubtful and possible deviation). Confounding variables were the primary caregivers consisting of parents or other than parents, screen time, and physical activity. This study was approved by the Research Ethics Committee of School of Medicine, Universitas Udayana/Sanglah Hospital.

\section{Results}

A total of 468 children met the inclusion and exclusion criteria during the study period from August to December 2019. The characteristics of the patients were shown in Table 1. Based on the assessment of the KPSP developmental pre-screening questionnaire, we found that the majority of participants had an appropriate developmental stage $(91.3 \%)$, followed by dubious results (5.3\%) and possible deviations (3.4\%). Interpretation of developmental pre-screening using KPSP is shown in Table 2.

Table 1: The characteristics of study subjects

\begin{tabular}{ll}
\hline Baseline characteristic & $\mathrm{n}=468$ \\
\hline Gender, $\mathrm{n}, \%$ & \\
Male & $227(48.5)$ \\
Female & $241(51.5)$ \\
Age (years), $\mathrm{n}, \%$ & \\
$2-3$ & $11(2.4)$ \\
$3-6$ & $457(97.6)$ \\
Nutritional status, $\mathrm{n}, \%$ & \\
Well nourished & $246(52.6)$ \\
Underweight & $98(20.9)$ \\
Severe underweight & $1(0.2)$ \\
Overweight & $62(13.3)$ \\
Obesity & $61(13)$ \\
Father's education, n, \% & \\
Uneducated & $4(0.9)$ \\
Primary school & $14(3)$ \\
Junior high school & $32(6.8)$ \\
Senior high school & $222(47.4)$ \\
Diploma & $7(1.5)$ \\
Bachelor & $189(40.4)$ \\
Mother's education, $\mathrm{n}, \%$ & $3(0.6)$ \\
Uneducated & $28(6)$ \\
Primary school & $38(8.1)$ \\
Junior high school & $200(42.8)$ \\
Senior high school & $15(3.2)$ \\
Diploma & $184(39.3)$ \\
Bachelor & \\
Family income, n, \% & $316(67.5)$ \\
According to the minimum wage & $152(32.5)$ \\
Below minimum wage & \\
Caretaker, n, \% & $388(82.9)$ \\
Parents & $79(16.9)$ \\
Other than parents & \\
\hline
\end{tabular}

Bivariate analysis showed that caregiver, physical activity, and screen time did not show a significant relationship with developmental disorders as shown in Table 3 . There was a statistically significant relationship between nutritional status and the risk of developmental delay (confidence interval [Cl] 95\%, 1.05-3.97). Multivariate analysis for variables that were considered significant $(p=0.25)$ as shown in Table 4

Table 2: Variables related to KPSP

\begin{tabular}{|c|c|c|c|}
\hline \multirow[t]{2}{*}{ Variable } & \multicolumn{3}{|c|}{ KPSP interpretation } \\
\hline & $\begin{array}{l}\text { Possible } \\
\text { deviation } n=16\end{array}$ & $\begin{array}{l}\text { Doubtful } \\
n=25\end{array}$ & $\begin{array}{l}\text { Appropriate } \\
n=427\end{array}$ \\
\hline \multicolumn{4}{|l|}{ Gender, n, \% } \\
\hline Male & $9(1.9)$ & $8(1.7)$ & $210(44.9)$ \\
\hline Female & $7(1.5)$ & $17(3.6)$ & $217(46.4)$ \\
\hline \multicolumn{4}{|l|}{ Nutritional status, n, \% } \\
\hline Well nourished & $9(1.9)$ & $6(1.3)$ & $231(49.4)$ \\
\hline Underweight & $2(0.4)$ & $9(1.9)$ & $87(18.6)$ \\
\hline Severe underweight & $0(0)$ & $0(0)$ & $1(0.2)$ \\
\hline Overweight & $5(1.1)$ & $7(1.5)$ & $50(10.7)$ \\
\hline Obesity & $0(0)$ & $3(0.6)$ & $58(124)$ \\
\hline \multicolumn{4}{|l|}{ Caretaker, n, \% } \\
\hline Parents & $13(2.8)$ & $17(3.6)$ & $359(76.8)$ \\
\hline Other than parents & $3(0.6)$ & $8(1.7)$ & $68(14.5)$ \\
\hline \multicolumn{4}{|c|}{ Physical activity (hour/day), n, \% } \\
\hline$<3$ & $4(0.9)$ & $3(0.6)$ & $106(22.6)$ \\
\hline$\geq 3$ & $12(2.6)$ & $22(4.7)$ & $321(68,6)$ \\
\hline \multicolumn{4}{|c|}{ Screen time (hour/day), n, \% } \\
\hline$>1$ & $1(0.2)$ & $6(1.3)$ & $99(22.6)$ \\
\hline$\leq 1$ & $15(3.2)$ & $19(4.1)$ & $328(70.1)$ \\
\hline
\end{tabular}


showed that malnutrition has a statistically significant relationship with the risk of developmental disorder (PR 2; Cl 95\%, 1.04-3.95).

Table 3: Bivariate analysis of child development

\begin{tabular}{|c|c|c|c|c|c|}
\hline \multirow[t]{2}{*}{ Nutritional status } & \multicolumn{3}{|l|}{ KPSP } & \multirow[t]{2}{*}{$\mathrm{Cl} 95 \%$} & \multirow[t]{2}{*}{$p$-value } \\
\hline & $\begin{array}{l}\text { Inappropriate } \\
\mathrm{n}=41\end{array}$ & $\begin{array}{l}\text { Appropriate } \\
\mathrm{n}=427\end{array}$ & PR & & \\
\hline \multicolumn{6}{|l|}{ Nutritional status, n, \% } \\
\hline Malnutrition & $26(5.6)$ & $196(41.9)$ & 2 & $1.05-3.97$ & 0.03 \\
\hline No malnutrition & $15(3.2)$ & $231(49.4)$ & & & \\
\hline \multicolumn{6}{|l|}{ Caretaker, n, \% } \\
\hline Other than parents & $11(2.4)$ & $68(14.5)$ & 1.8 & $0.95-3.45$ & 0.075 \\
\hline Parents & $30(6.4)$ & $359(76.7)$ & & & \\
\hline \multicolumn{6}{|c|}{ Physical activity (h/day), n, \% } \\
\hline$<3$ & $7(1.5)$ & $106(22.6)$ & 0.65 & $0.29-1.42$ & 0.27 \\
\hline$\geq 3$ & $34(7.3)$ & $321(68.6)$ & & & \\
\hline \multicolumn{6}{|c|}{ Screen time (h/day), n, \% } \\
\hline$>1$ & $7(1.5)$ & $99(21.2)$ & 0.703 & $0.32-1.54$ & 0.37 \\
\hline$\leq 1$ & $34(7.26)$ & $328(70.1)$ & & & \\
\hline
\end{tabular}

\section{Discussion}

Most of the subjects had appropriate developmental stages according to age and suspicion of developmental disorders occurred in $8.6 \%$ of children. This result is in accordance with the theory that early childhood (0-6 years) is an important period in growth and development as it accounts for almost $95 \%$ of adult brain development [12], [13]. This period is the most appropriate time to develop the physical ability, language skills, social-emotional skills, self-concept, moral arts, religious values, and independence [14]. This result is lower than the research by Dhamayanti et al., involving children aged 15-18 months in the slum area of the Puskesmas work area, in which the percentage of children with suspicion of developmental disorders is $15 \%$. [15].

Table 4: Multivariate analysis of developmental disorders based on KPSP

\begin{tabular}{lllll}
\hline Variable & $\mathrm{B}$ & $\mathrm{PR}$ & $\mathrm{Cl} 95 \%$ & $\mathrm{p}$-value \\
\hline Malnutrition & 0.7 & 2 & $1.04-3.95$ & 0.038 \\
Caretaker by other than parents & 0.6 & 1.85 & $0.88-3.9$ & 0.1 \\
\hline Cl: Confidence interval, KPSP: Kuesioner Pra Skrining Perkembangan. & &
\end{tabular}

Malnutrition refers to deficiencies, excess, or imbalance in energy and/or nutritional intake, which includes undernutrition (stunting, wasting, underweight) and overweight [16]. Overweight and obesity in children have become a global epidemic and one of the health problems in the world that must be addressed seriously. Data from the WHO in 2007 stated that 22 million children under 5 years of age are overweight [17]. Data from Riskesdas in 2013 showed that the prevalence of obese children under 5 years old is $11.9 \%$ [18]. This study found that malnutrition increases the likelihood of developmental disorders in children by two times. This result was in accordance with the theoretical review which stated that a person who has a good nutritional status reflects normal growth and developmental level according to age [19]. It is also in accordance with a study by Soetjiningsih et al., in 2010 which explained that nutritional status was one of the determinants of child development where malnutrition will inhibit the rate of child development [20]. The development of children including cognitive, motor, language, and skills will be hampered compared to children who have good nutritional status [19]. Mugianti et al., stated on their study that the majority of their subjects showed abnormality in gross motoric development [17]. In this study, the malnutrition group which included children with overweight and obese nutritional status showed a significant association with the risk of developmental disorders in children.

Child development depends on the quality of care from the environment. Parents are the primary providers of childcare and their strategies, relationships and interactions will have an impact on aspects of children development. Children who live with their father and mother have better developmental rates than those who live with only their father or mother or caregiver. Parents can immediately recognize abnormalities in the child's development process as early as possible and provide comprehensive stimulation of physical, mental, social, and independency [21].

A study by Glascoe et al., found that among children with undiagnosed developmental disorders, $80 \%$ had parents who expressed developmental concerns. [22]. In this study, there was no significant difference in the developmental status of children cared by parents, family other than their parents (grandparents), or caregiver. This study is in line with research by Latifah et al. who found that good cognitive function and independence were found in children who were cared by their grandmothers [23]. This illustrates a multifactorial process related to parenting and development which can include children's attachment to caregivers, the care system, and the level of education of the caregiver.

The duration of physical activity that affects developmental stimulation is categorized by age and type of physical activity. Children $<1$ year old should have physical activity for at least $30 \mathrm{~min}$ in the form of interactive play on the floor and no restraint for more than $1 \mathrm{~h}$. Children aged 1-2 years are advised to have physical activity for at least $180 \mathrm{~min}$ with activity varying from moderate to severe intensity and children aged 3-4 years are also advised to have physical activity for at least 180 min with moderate intensity and $60 \mathrm{~min}$ with vigorous intensity [24]. This study found that physical activity in children had no effect on the risk of developmental disorder in children based on KPSP. It may be because this study did not evaluate the type and intensity of the physical activity.

The development of new technology and changes in family routines have raised concerns about the potential unexpected impacts. In response to reports from infants and toddlers watching television, AAP issued a statement in 2016 recommending that 
parents should avoid children $<2$ years of age from watching television [25]. This study found that screen time activity in children had no effect on children's development status based on KPSP. This result was different from the research by Perdana et al., which stated that children who are exposed to television for more than $4 \mathrm{~h} /$ day have a four times greater risk of experiencing speech delays [26]. This was because, in this study, the screen time activity was evaluated only in the form of the duration of playing gadgets or watching television.

There were several limitations of this study. This study did not describe the general characteristics of the nutritional status of children, as well as the association between nutritional status and the risk of developmental disorders in children in general because the samples were only taken from urban areas. In addition, this study did not evaluate screen time as a confounding variable that may cause bias.

\section{Conclusion}

This study concluded that malnourished children had a likelihood of experiencing delay in development based on KPSP. Further prospective study by standard assessment tools is required to evaluate the association between nutritional status and developmental level in children.

\section{References}

1. Bolajoko MR. Growth pattern and nutritional status of under five children in Owo local government area of Ondo state, Nigeria. IOSR J Pharm Biol Sci. 2013;5(4):106-9. https://doi. org/10.9790/3008-054106109

2. Hurley KM, Yousafzai AK, Lopez-Boo F. Early child development and nutrition: A review of the benefits and challenges of implementing integrated interventions. Adv Nutr. 2016;7(2):357-63. https://doi.org/10.3945/an.115.010363 PMid:26980819

3. Rosales FJ, Reznick JS, Zeisel SH. Understanding the role of nutrition in the brain and behavioral development of toddlers and preschool children: Identifying and overcoming methodological barriers. Nutr Neurosci. 2009;12(5):190-202. https://doi. org/10.1179/147683009x423454

PMid: 19761650

4. Kusuma IR, Salimo H, Sulaeman ES. Path analysis on the effect of birth weight, maternal education, stimulation, exclusive breastfeeding and nutritional status toward motor development of children aged 6-24 months in Banyumas regency. Matern Child Health J. 2017;2(1):64-75. https://doi.org/10.26911/ theicph.2017.096

5. Diana FM. Pemantauan perkembangan anak balita. J Kesehatan Masyarakat. 2010;4:116-29.
6. Wani YA, Wilujeng CS, Rahmi Y. Kusuma TS, Rahmawati W, Fadhilah $\mathrm{E}$, et al. Survei status gizi dan perkembangan anak balita menggunakan kuesioner praskrining perkembangan (KPSP). Majalah Kesehatan FKUB. 2017;4(4):193-9. https://doi. org/10.21776/ub.majalahkesehatan.2017.004.04.23

7. Rosela E, Hastuti TP, Triredjeki H. Hubungan status gizi dengan perkembangan anak usia 1 sampai 5 tahun di kelurahan Tidar Utara, kota Magelang. Jurnal Keperawatan Soedirman. 2017;12:27-37. https://doi.org/10.20884/1. jks.2017.12.1.686

8. Ariati NN, Fetria A, Padmiari IA, Purnamawati AA, Sugiani PP, Suarni NN. Description of nutritional status and the incidence of stunting children in early childhood education programs in Bali-Indonesia. Bali Med J. 2018;7(3):723-26. https://doi. org/10.15562/bmj.v7i3.1219

9. Trisna Windiani IG, Sugitha Adnyana IG, Soetjiningsih I. The sensitivity and specificity of kuisioner praskrining perkembangan to detect delayed developmental in children. Am J Pediatr. 2020;6(1):42-5. https://doi.org/10.11648/j. ajp.20200601.17

10. Gunawan G, Fadlyana E, Rusmil K. Hubungan status giz dan perkembangan anak usia 1-2 tahun. Sari Pediatri. 2011;13:142-6. https://doi.org/10.14238/sp13.2.2011.142-6

11. Riset Kesehatan Dasar (Riskesdas). Badan Penelitian dan Pengembangan Kesehatan Kementrian RI Tahun; 2018. Available from: http://www.depkes.go.id/resources/download/ infoterkini/materirakorpop2018/Hasil\%20Riskesdas\%202018. pdf. [Last accessed on 01 Dec 2020].

12. Arini $D$, Mayasari AC, Rustam MZ. Gangguan perkembangan motoric dan kognitif pada anak toddler yang mengalami stunting di wilayah pesisir Surabaya. J Health Sci Prev. 2019;3(2):122-8. https://doi.org/10.29080/jhsp.v3i2.231

13. Santrock JW. Perkembangan Anak. $7^{\text {th }}$ ed. Jakarta: Erlangga; 2011.

14. Wiyani A. Save Our Children from School Bullying. Jogjakarta: Arrus Media; 2012.

15. Dhamayanti M. Kuesioner praskrining perkembangan (KPSP) anak. Sari Pediatri. 2006;8:9-15. https://doi.org/10.14238/ sp8.1.2006.9-15

16. Blossner M, Onis MD. Malnutrition. Envirn Burden Dis Series. 2005;12:1-43.

17. Mugianti S, Setijaningsih T, Fransiska K. Perkembangan motorik balita obesitas usia 3-5 tahun. J Ners Kebidanan. 2018;5:46-52. https://doi.org/10.26699/jnk.v5i1.art.p046-052

18. Riset Kesehatan Dasar (Riskesdas). Badan Penelitian dan Pengembangan Kesehatan Kementrian RI; 2013. Available from: http://www.depkes.go.id/resources/download/general/ Hasil\%20Riskesdas\%202013.pdf. [Last accessed on 01 Dec 2020].

19. Jimoh AO, Anyiam JO, Yakubu AM. Relationship between child development and nutritional status of under-five Nigerian children. South Afr J Clin Nutr. 2018;31(3):50-4. https://doi.org/1 0.1080/16070658.2017.1387434

20. Soetjiningsih. Tumbuh Kembang Anak. Jakarta: ECG Penerbit Buku Kedokteran; 2010.

21. Departemen Kesehatan RI. Pedoman Pelaksanaan Stimulasi. Deteksi dan Intervensi Dini Tumbuh Kembang Anak di Tingkat Pelayanan Kesehatan Dasar. Jakarta: Depkes RI; 2009. https:// doi.org/10.25077/jka.v8i4.1133

22. Glascoe FP, Dworkin PH. The role of parents in the detection of developmental and behavioral problems. Pediatrics. 1995;95(6):829-36.

PMid:7539122

23. Latifah EW, Krisnatuti D, Puspitawati H. Pengaruh pengasuhan ibu dan nenek terhadap perkembangan kemandirian dan kognitif anak usia prasekolah. Jur IIm Kel Kons. 2016;9(1):21-31. https:// 
doi.org/10.24156/jikk.2016.9.1.21

24. World Health Organization. New WHO Guidelines on Physical Activity, sedentary Behaviour and Sleep for Children Under 5 Years of Age. A review. Geneva: World Health Organization; 2019.

25. American Academy of Pediatrics. Identifying infants and young children with developmental disorders in the medical home: An algorithm for developmental surveillance and screening.
Pediatrics. 2016;118(1):405-20. https://doi.org/10.1542/ peds.2006-1231

PMid:16818591

26. Perdana SA, Medise BE, Purwaningsih EH. Duration of watching TV and child language development in young children. Paediatr Indones. 2017;57(2):99-100. https://doi.org/10.14238/ pi57.2.2017.99-103 